\begin{tabular}{c} 
International Journal of Engineering \& Technology, 7 (3.15) (2018) 19-23 \\
International Journal of Engineering \& Technology \\
SPC \\
Website: www.sciencepubco.com/index.php/IJET \\
Research paper \\
\hline
\end{tabular}

\title{
A Review of Kinect Computing Research in Education and Rehabilitation
}

\author{
Sara Reisi Dehkordi*, Marina Ismail, Norizan Mat Diah \\ Faculty of Computer and Mathematical Sciences \\ University Technology MARA \\ 40450 Shah Alam, Selangor \\ Malaysia \\ *Corresponding author E-mail: sarahraissy@yahoo.com
}

\begin{abstract}
Recently Kinect technology device and its benefit in treatment approach are rapidly growing domain of interestingness for res earchers and educators. For years, the games and applications, except their entertaining aspect, have discovered an educational and rehabilitation character. In recent years, gesture-based devices have evolved and attracted the attention of researchers, and thus to Microsoft Kinect Xbox. Already, many institutions worldwide use the Kinect to the learning or rehabilitation process. This paper indicates a review of articles to provide a preliminary reconsideration on Microsoft's Kinect for the Xbox 360. The 16 researches were reviewed in this study are in the filed of education or rehabilitation implemented to users with special needs. The distribution and reviews in the study were research methods, domain of research, learning content, and intended settings of the kinect system. The outcome of this study is the possible uses and limitations of kinect for education and rehabilitation.
\end{abstract}

Keywords: Use about five key words or phrases in alphabetical order, Separated by Semicolon.

\section{1) Introduction}

Kinect system had received great attention in treatment goals; interest in Kinect system within the domain of rehabilitation or education is on the rise as reflected in a growing number of researches on this subject. A number of collaborative games, software and applications have been deployed on motion capture devices such as Kinect in treatment or education activity. Therapeutic and educational activities with Kinect have been designing and developing in numerous domains such as special treatment, sport, mental therapy, physical therapy, painting, mathematics, etc.

In comparison with other gesture recognition devices, which use sensors to capture movement, Kinect is more beneficial and helpful. Microsoft Kinect sensors give researchers the real time position $(\mathrm{x}, \mathrm{y}, \mathrm{z})$ of the player's joints. Kinect is a webcam-style sensor box with RGB camera developed for the Xbox games console, low cost, and easy to install device. Applications on Kinect device provide reliable and potentially valuable results.

Kinect appear as a promising and helpful tool that provides potentially valuable results for different fields of education or rehabilitations. In this paper several researches on Kinect with the educational or rehabilitation goals for individuals with developmental disability will be presented. The advantage of Kinect also encourages educators to evaluate its feasibility in education. As Kinect can actively track users so teachers and students can control learning materials by their body and voice without being bothered by wired or wireless devices [1]. Consequently, Kinect seems to apply natural interactive experiences for caregivers and students with special needs. Embodied cognition provides a theoretical under- pinning for the educational potential of touch less motion-based games [2].

\section{2) Research method}

The goal of this research is to provide a comprehensive review about the scientific characteristic of existing studies on (Kinect) motion based computing in the filed of rehabilitation or education. The data collection in this research is based on the papers were published in academic journals in the field of computer science. The data analyzed in this research cover research articles published in academic journals from the years 2010 through 2016. The data was first retrieved individually from online databases such as Elsevier, SAGE, Springer and the Institute of Electrical and Electronics Engineers (IEEE).

As a first step there was numerous key words were used when searching articles such as software-based touch less motion, $\mathrm{Ki}$ nect-based game, Microsoft Kinect motion sensor, etc., as a topic. Relying on research experience, it was important to utilize numerous terms to find out related articles. Articles were located using keyword Kinect and combination sets of following: motion interaction system, rehabilitation, education and gesture recognition.

As a next step of data collection approximately 55 articles were selected and afterward were sifted manually by the analysts in light of the titles, keywords and abstract of the papers. In some cases, entire papers were read independently according to the topic and the main idea. The necessary notes were taken and relevant categories were classified. Total of 16 studies were identified as being related to the topic of this paper and were reviewed in this research. All data gathered from studies and categories were rec- 
orded in detail, the result is discussed on next sections in this study.

\section{3) Results and Analysis}

The main categories for reviewing based on [3] are (a) target of research; (b) type of research; (c) domain of the research; (d) the setting in which the study intended to implement the technology; (e) Significant finding; This section of the review covers some analysis about type of the research such as experimental research, design based approach and other. Details about the learning area such as domain of study and target users for education or rehabilitation were also considered. This information provides a context that demonstrates why Kinect has become an important issue of central concern in relation to educational provision. Table 1 shows the details about researches.

Table 1: The detailes about researches

\begin{tabular}{|c|c|c|}
\hline Author & $\begin{array}{l}\text { Target of re- } \\
\text { search } \\
\text { Type of research } \\
\text { Domain of re- } \\
\text { search } \\
\text { Setting }\end{array}$ & Significant finding \\
\hline $\begin{array}{l}\text { (Bartoli \& } \\
\text { Lassi, 2015) }\end{array}$ & $\begin{array}{l}\text { Target of re- } \\
\text { search: } 27 \text { partic- } \\
\text { ipants different } \\
\text { age group } \\
\text { Type of research: } \\
\text { Experimental } \\
\text { Domain of re- } \\
\text { search: Motor } \\
\text { skills } \\
\text { Setting: Clinic }\end{array}$ & $\begin{array}{l}\text { This research proposed custom- } \\
\text { ized software motion-based } \\
\text { touchless for individuals with } \\
\text { ASD focus on motor area. Using } \\
\text { children`s contribution in design } \\
\text { approach promote stronger step- } \\
\text { by-step results. Applying kinect } \\
\text { software led some players imi- } \\
\text { tates some of the treatment's } \\
\text { movement in real life. }\end{array}$ \\
\hline $\begin{array}{l}\text { (Chang, Chen, } \\
\text { \& Huang, 2011) }\end{array}$ & $\begin{array}{l}\text { Target of re- } \\
\text { search: Two } \\
\text { young adults (16 } \\
\text { and } 17 \text { years old) } \\
\text { Type of research: } \\
\text { Experiment } \\
\text { ABAB design } \\
\text { Domain of re- } \\
\text { search: Motor } \\
\text { impairments } \\
\text { Setting: Public } \\
\text { school }\end{array}$ & $\begin{array}{l}\text { This research indicates that using } \\
\text { image processing technology for } \\
\text { people with motor disability } \\
\text { improve physical performances } \\
\text { during treatment. Audio and } \\
\text { video feedbacks in the game are } \\
\text { the important factors that in- } \\
\text { crease motivation of participants } \\
\text { in rehabilitation. }\end{array}$ \\
\hline $\begin{array}{l}\text { (Gonçalves, } \\
\text { Costa, } \\
\text { Rodrigues, \& } \\
\text { Soares, 2014) }\end{array}$ & $\begin{array}{l}\text { Target of re- } \\
\text { search: Seven } \\
\text { adults } \\
\text { Type of research: } \\
\text { Case study } \\
\text { Domain of re- } \\
\text { search: Hand } \\
\text { flapping move- } \\
\text { ments } \\
\text { Setting: School } \\
\text { with special need }\end{array}$ & $\begin{array}{l}\text { This research proposed an in- } \\
\text { strument to monitor and analyze } \\
\text { stereotypes movement about } \\
\text { children with ASD on kinect. } \\
\text { The finding shows noise signals } \\
\text { can affect the final result. During } \\
\text { evaluation sessions if users left } \\
\text { the kinect sensors area, move- } \\
\text { ment recognition cannot deter- } \\
\text { mine correctly. }\end{array}$ \\
\hline $\begin{array}{l}\text { (Uzuegbunam, } \\
\text { Wong, Cheung, } \\
\text { \& Ruble, 2015) }\end{array}$ & $\begin{array}{l}\text { Target of re- } \\
\text { search: } 3 \text { boys } \\
\text { with autism, aged } \\
7 \text { to } 12 \\
\text { Type of research: } \\
\text { Experimental } \\
\text { multiple-baseline } \\
\text { single } \\
\text { Domain of re- }\end{array}$ & $\begin{array}{l}\text { MEBOOK in this research is a } \\
\text { customized game, which is a } \\
\text { combination of three compo- } \\
\text { nents: video self-modeling, social } \\
\text { greeting rules and evidence- } \\
\text { based interventions. The men- } \\
\text { tioned factors are very important } \\
\text { to increase the social greeting } \\
\text { abilities for users with ASD. }\end{array}$ \\
\hline
\end{tabular}

\begin{tabular}{|l|l|l|}
\hline & $\begin{array}{l}\text { search: Greeting } \\
\text { behaviors } \\
\text { Setting: - }\end{array}$ & \\
\hline & Target of re- & This research presens the ine-
\end{tabular}

(Malinverni,

Mora-guiard,

Padillo, Valero,

\& Pares, 2016)

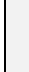

\section{Target of re-} search: 10 children ( 4 to 6 years old)

Type of research:

Experimental

design

Domain of re-

search: Promot-

ing social inter-

action

Setting: Hospital

\begin{tabular}{l|l} 
(Lui, Wong, Ng, & $\begin{array}{l}\text { Target of re- } \\
\text { search: } 20 \text { stu }\end{array}$ \\
\hline L Law, 2012) & dents
\end{tabular}

(

\section{(}

\begin{tabular}{|l|l|l|}
$\begin{array}{l}\text { Experimental } \\
\text { design }\end{array}$ & $\begin{array}{l}\text { stress relaxation tools. In this } \\
\text { Domain of re- } \\
\text { study traditional therapeutic } \\
\text { images present in the form of } \\
\text { ment for mental } \\
\text { stress sufferers } \\
\text { Setting: - }\end{array}$ & $\begin{array}{l}\text { virtual graphics and player can } \\
\text { interact with virtual objects. Soft } \\
\text { music and real life scenarios are } \\
\text { the factors were considered in } \\
\text { design phase. }\end{array}$ \\
\hline &
\end{tabular}

This research presents the integration of children's contribution and experts` review in design phase of developing video game to promote social imitation for children with ASD. Poor game design will cause failed to achieve the goal of the therapeutic game and engagement.

AIMtechKinect is an interactionoriented gesture recognition framework for children with severe intellectual disabilities (SID). The users were participated in this study were exciting when enjoying the VR contents. This should be under consideration during the evaluation; some gestures may not be easy for the sensors to recognize.

\begin{tabular}{|l|l|l|} 
& $\begin{array}{l}\text { tion } \\
\text { Setting: Special } \\
\text { school }\end{array}$ & sensors to recognize. \\
\hline & &
\end{tabular}

(Roy, Soni, \& Target of reDubey, 2013) search: 6 participants

Type of research: Effectiveness Domain of research: Motor Rehabilitation Setting: -

Kinect-o-therapy has been presented in this research as a serious game for children with physical disability who are bored and tired from rehabilitation sessions. The effective rehabilitation results depend on the motivation for children. Using serious games on kinect would be easy to use and affordable tool and would require no maintenance costs, unlike the machines used in conventional therapy.

(Weng et al., 2015)
Target of research: 45 typically individuals Type of research: Design-based research usability Domain of research: Emotional Information Setting: Large conference room

\begin{tabular}{l|l|} 
& \\
\hline $\begin{array}{l}\text { (Gabriel, Melo, } \\
\& \text { Machado, }\end{array}$ & $\begin{array}{l}\text { Target of re- } \\
\text { search: } 11 \text { partic- }\end{array}$ \\
\hline
\end{tabular}

This research presents a connection between video gameplay environment and psychological factors to teach facial expression for children with ASD. In evaluation part when a user cannot attend to interview sessions or cannot fill a questionnaire a direct measurement administered by a trained psychologist may be more accurate and result in stronger relationships rather than observe the reaction of users.

This study presents a virtual reality game system for cardio- 


\begin{tabular}{|c|c|c|}
\hline 2016) & $\begin{array}{l}\text { ipants } 40 \text { to } 75 \\
\text { years old } \\
\text { Type of research: } \\
\text { Experimental } \\
\text { Domain of re- } \\
\text { search: cardio- } \\
\text { vascular rehabili- } \\
\text { tation } \\
\text { Setting: home }\end{array}$ & $\begin{array}{l}\text { vascular rehabilitation. } \\
\text { The game has been designed } \\
\text { based on the therapist`s review. } \\
\text { Proposing a home-based game on } \\
\text { kinect device for rehabilitation of } \\
\text { adult in the field of cardiovascu- } \\
\text { lar provide positive feedback } \\
\text { from users, especially for those } \\
\text { who cannot afford the expenses } \\
\text { related to rehabilitations in hospi- } \\
\text { tals or clinics. }\end{array}$ \\
\hline $\begin{array}{l}\text { (Clark et al., } \\
\text { 2012) }\end{array}$ & $\begin{array}{l}\text { Target of re- } \\
\text { search: } 30 \text { stroke } \\
\text { patient } \\
\text { Type of research: } \\
\text { experimental } \\
\text { Domain of re- } \\
\text { search: Gait } \\
\text { impairments } \\
\text { rehabilitation } \\
\text { Setting: Clinic }\end{array}$ & $\begin{array}{l}\text { The goal of this research is to } \\
\text { specify if instrumenting a gait } \\
\text { assessment using the Kinect } \\
\text { provides reliable and potentially } \\
\text { valuable information in compari- } \\
\text { son with the standard treatment. } \\
\text { The findings provide support for } \\
\text { the potential usefulness of im- } \\
\text { plementing a Kinect instrument- } \\
\text { ed gait assessment in a clinical } \\
\text { setting. }\end{array}$ \\
\hline $\begin{array}{l}\text { (Mobini, } \\
\text { Behzadipour, \& } \\
\text { Saadat, 2015) }\end{array}$ & $\begin{array}{l}\text { Target of re- } \\
\text { search: } 18 \text { stroke } \\
\text { patient } \\
\text { Type of research: } \\
\text { Test- } \\
\text { retest reliability } \\
\text { research } \\
\text { Domain of re- } \\
\text { search: Motion } \\
\text { rehabilitation } \\
\text { Setting: clinic }\end{array}$ & $\begin{array}{l}\text { The findings from this study } \\
\text { highly recommending the design } \\
\text { and development of home-based } \\
\text { rehabilitation systems using } \\
\text { Kinect as an affordable motion } \\
\text { capture sensor for upper body } \\
\text { recovery of stroke patients. }\end{array}$ \\
\hline $\begin{array}{l}\text { (Sommool, } \\
\text { Battulga, Shih, } \\
\text { \& Hwang, } \\
\text { 2013) }\end{array}$ & $\begin{array}{l}\text { Target of re- } \\
\text { search: } 20 \text { partic- } \\
\text { ipants } \\
\text { Type of research: } \\
\text { Design-based } \\
\text { research- usabil- } \\
\text { ity test } \\
\text { Domain of re- } \\
\text { search: e-learning } \\
\text { in classroom } \\
\text { Setting: school }\end{array}$ & $\begin{array}{l}\text { The results from this study pre- } \\
\text { sent using kinect in learning } \\
\text { environment classroom for prac- } \\
\text { tical usage such as gesture-based } \\
\text { controlling play a role as a con- } \\
\text { nection between students and } \\
\text { teacher. Findings show this sys- } \\
\text { tem provides facility for teachers } \\
\text { and engage students by providing } \\
\text { easy to understand and easy to } \\
\text { setup tool. }\end{array}$ \\
\hline $\begin{array}{l}\text { (Nakamura et } \\
\text { al., 2013) }\end{array}$ & $\begin{array}{l}\text { Target of re- } \\
\text { search: } 5 \text { partici- } \\
\text { pants } \\
\text { Type of research: } \\
\text { Experimental } \\
\text { study } \\
\text { Domain of re- } \\
\text { search: Nursing } \\
\text { care skills } \\
\text { Setting: Lab } \\
\text { room }\end{array}$ & $\begin{array}{l}\text { This research clarified the rela- } \\
\text { tionship between nursing stu- } \\
\text { dents' trend towards learning and } \\
\text { effects of Kinect self-learning } \\
\text { system for skill. Self-learning } \\
\text { system on kinect provide a suita- } \\
\text { ble environment for students to } \\
\text { practice several times and receive } \\
\text { feedback from the system to } \\
\text { identify their weaknesses after } \\
\text { each performance. }\end{array}$ \\
\hline (Rahman, 2015) & $\begin{array}{l}\text { Target of re- } \\
\text { search: } 1 \text { hemi- } \\
\text { plegic participant } \\
\text { Type of research: } \\
\text { Experimental } \\
\text { design } \\
\text { Domain of re- } \\
\text { search: Motor } \\
\text { skills } \\
\text { Setting: hospital }\end{array}$ & $\begin{array}{l}\text { This study presents a multisenso- } \\
\text { ry serious game-based therapy on } \\
\text { Kinect can be adjust by therapists } \\
\text { to design a therapy method or } \\
\text { combine several therapies to- } \\
\text { gether for users. In some cases } \\
\text { the treatment can be mapped to a } \\
\text { set of body joints and motions. }\end{array}$ \\
\hline $\begin{array}{l}\text { (Kayama, } \\
\text { Nishiguchi, \& }\end{array}$ & $\begin{array}{l}\text { Target of re- } \\
\text { search: } 41 \text { partic- }\end{array}$ & $\begin{array}{l}\text { This study shows Dual-Task Tai } \\
\text { Chi (DTTC), using Kinect (Mi- }\end{array}$ \\
\hline
\end{tabular}

\begin{tabular}{|l|l|l|}
\hline Yamada, 2013) & ipants & crosoft Co.), a motion-capture \\
Type of research: & device, and demonstrated that the \\
Domain of re- & DTTC test can quantitatively \\
search: executive & evaluate various functions that \\
cognitive per- & are known risk factors for falling \\
formance & in elderly adults. \\
Setting: - &
\end{tabular}

\subsection{Target of Research}

In a few researches that focus on motor skills or psychological treatment the learning systems has been customized and designed based on the limitations of the participants with Autism Spectrum Disorder (ASD). Examples include problems about participants with ASD such as physical activity, therapeutic objectives or emotional problems. In this review five researches out of 16 researches were related to design a system with specific goal about ASD. For example, [2] created a software that considered the motor area for children with ASD. The software tested on five different age groups: five children with ASD (10-12 years old) and 10 children (6-8 years old) the next group contains 4 children (18-20 years old) and the last group 8 children (11-12 years old).

[5] provides valuable tool to monitor interaction skills in children with ASD and tested on 7 adults without any associated pathologies. MEBOOK proposed by [6] is another example of social narrative game which tested on a total of 3 boys with ASD, aged 7 to 12. [7] Proposed Pico's Adventures as a Kinect-based game aimed at promoting social initiation in children with ASD, which tested on 10 children (4 to 6 years old) with ASD. [11] Focus on emotional information which is one of the problems about children with ASD and tested on 45 typically individuals.

Another groups of targets of the researches in this study are for rehabilitation such as [19] proposed a system for physical rehabilitation, called the Kinerehab and tested on two young adults(16 and 17) for rehabilitation goals. Relying on review from articles, for rehabilitation, the age of the learners does not often fall into the typical age classification found in most education systems [3]. Systems which could deeply affect the life of adult stroke patients, has been developed by [14] and [15].[12] is another study with rehabilitation goal that tested on 11 participants (40 to 75 years old). As a result in the words of Hobson, 'There is no better way to begin to understand people, whether 'normal' or disabled, whether adult or child, than to observe and examine a few individuals very closely' (Hobson 2002, page 9).

\subsection{Type of Research}

This section explains type of the each research from the perspective of the design of the studies and the methodology were used in these researches. Research methods indicate the process used to collect and analyzed information and data for the specific purpose. Each type of research uses different research methodology and goals.

In this review two studies were design-based to generate design framework and recommendation for therapy treatment on Kinect. Most of the researches in this study used an experimental design and one of them used the A-B-A-B reversal design that indicates behavior change during different steps in which $\mathrm{A}$ indicates the baseline and $\mathrm{B}$ indicates intervention phases. The main focus in A$\mathrm{B}-\mathrm{A}-\mathrm{B}$ design method is on the behavioral change of each individual and compares these changes in different time.

In some studies multiple methods were employed such as qualitative methods like observation, questionnaire and interviews to achieve the aims of the research. Some researchers focus especially on effectiveness or usability of studies with specific focus on observations of interaction with the study. About 9 studies out of 16 studies in this research used an experimental design. The results in this section presents that the major process of the current research in the field of Kinect is trying to prove the concept that 
the application of gesture-based computing can support teaching and learning by measuring the effect of gesture-based learning "systems" on learning performance [3]

\subsection{Domain of Research}

Most studies focus clearly into physical movements, such as motor skills, hand flapping or gesture recognition. There are two studies that focus on social behavioral and emotional learning. The topics related kinect therapy or education domains vary. The research topics in this study are almost similar in the field that the main objective or target abilities to learn were kinetic-centered. Three of researches focus on stroke and old people for daily living tasks as technologically advanced alert support systems are a potential avenue of assistance for the independently living elderly person [20]. Aided game therapy can bring a sense of motivation, as well as being a useful way for individuals to do the exercises in addition to traditional methods. In case of domain of the studies, all of the studies indicated motor skills would help users in acquiring knowledge such as observational learning or stimulation environments learning.

\subsection{Intended Setting}

As table 1 shows most of the kinect learning implementations conducted at the classroom/school/clinic for learning, treatment, rehabilitation or physical therapy goals. Relying on some parts of these studies, which are related to education, it is clear that the intended setting of the learning system designed is the classroom or school.

However, given the changes in goal of researches in rehabilitation purposes resulting such as physical or mental categories for rehabilitation setting are testing in hospitals or clinic centers. The result of the review indicates that the settings mentioned in the studies, the implementations of kinect systems can be applied to multiple settings as well.

\section{Limitations of Kinect-Based Therapeutic or Educa- tional Systems}

As the Kinect is a relatively new device of hardware for education or rehabilitation this study provide a list of current limitations of Kinect that we noted based on our review:

a) Limitations in motion capture of participants and gesture recognition because of the lack of space.

b) The height of adult participants and the objects between the player and the researcher or Kinect device did not allow the system to correctly detect the participant's movement.

c) Kinect systems cannot support for several disabled patients.

d) The Kinect sensor should be fixed to a certain location and has a range of capture of around ten meters, it means any movement should occur in front of the sensors only.

\section{Conclusion}

The present paper has reviewed a total of 16 studies about using kinect computing in the rehabilitation or education domain. Besides the researches proved beneficial relations between kinect systems and training abilities, games' added value to entertaining aspect. In fact where education or rehabilitation treatments for users can be painful or boring, kinect system act a role as a third party motivator. Kinect systems provide a virtual world, which can be customized and designed on the target's limitations.

Learning content, domain and target of the research, and the intended setting of the kinect were considered as a main category of review. As a first step, it was necessary to identify the terms asso- ciated with Kinect-Based systems and the differences between them. Relying on information from table 1 the outcomes of the researches show that kinect computing system is a developing asset in treatment, rehabilitation and education.

Findings from this review suggest kinect system provides facility for caregivers (therapists /teachers/doctors/parents) in the form of serious game, software, E-learning environment and etc., in several cases design components should be under consideration such as using participants` favorite objects and stories, design a real life scenario, audio and video feedbacks and etc., to engage the user. In this review using Kinect in studies show notable accessibly and beneficial to a population of participants, which needs therapy of educational treatment. However, some significant technological limitations mentioned such as: detection problem in small spaces or between objects and participants.

Regarding the domain and types of research were reviewed in this study, procedural types of learning such as Motor skills learning (Including rehab), Behavior skills training and Physical Activity are well supported by the Kinect.

\section{References}

[1] H. J. Hsu, "The Potential of Kinect as Interactive Educational Technology," 2nd Int. Conf. Educ. Manag. Technol., vol. 13, pp. 334-338, 2011.

[2] L. Bartoli and S. Lassi, "Experimental Study of Results Obtained from the Interaction with Softwares Motion-based Touchless Created for Habilitation-rehabilitation in users with Diagnosis of Autism Spectrum Disorders," Procedia Manuf., vol. 3, no. Ahfe, pp. 5176-5183, 2015.

[3] F. R. Sheu and N. S. Chen, "Taking a signal: A review of gesturebased computing research in education," Comput. Educ., vol. 78, pp. 268-277, 2014

[4] Y. Chang, S. Chen, and J. Huang, "Research in Developmental Disabilities A Kinect-based system for physical rehabilitation : A pilot study for young adults with motor disabilities," Res. Dev. Disabil., vol. 32, no. 6, pp. 2566-2570, 2011.

[5] N. Gonçalves, S. Costa, J. Rodrigues, and F. Soares, "Detection of stereotyped hand flapping movements in Autistic children using the Kinect sensor: A case study," in 2014 IEEE International Conference on Autonomous Robot Systems and Competitions, ICARSC 2014, 2014, pp. 212-216.

[6] N. Uzuegbunam, W. Wong, S. S. Cheung, and L. Ruble, "MEBOOK : KINECT-BASED SELF-MODELING INTERVENTION FOR CHILDREN WITH AUTISM Department of Electrical \& Computer Engineering and Department of Educational, School and Counseling Psychology University of Kentucky, Lexington KY," Multimed. Expo (ICME), 2015 IEEE Int. Conf., no. 1237134, 2015

[7] L. Malinverni, J. Mora-guiard, V. Padillo, L. Valero, and N. Pares, "An inclusive design approach for developing video games for children with Autism Spectrum Disorder," 2016.

[8] A. K. a. K.-F. ; K.-F. W. ; S.-C. N. ; K.-H. L. Lui, K. Wong, S. Ng, and K. Law, "Development of a Mental Stress Relaxation Tool based on Guided Imagery and Microsoft Kinect," Distrib. Smart Cameras (ICDSC), 2012 Sixth Int. Conf., p. 11/2012, 2012.

[9] C. Li and H. H. S. Ip, "AIMtechKinect: A Kinect based interactionoriented gesture recognition system designed for students with severe intellectual disabilities," in Proceedings - 13th International Conference on Computer-Aided Design and Computer Graphics, CAD/Graphics 2013, 2013, pp. 322-329.

[10] A. K. Roy, Y. Soni, and S. Dubey, "Enhancing effectiveness of motor rehabilitation using kinect motion sensing technology," in Global Humanitarian Technology Conference: South Asia Satellite (GHTC-SAS), 2013 IEEE, 2013, pp. 298-304.

[11] M. Weng, C. A. Wall, E. S. Kim, L. Whitaker, M. Perlmutter, Q. Wang, E. R. Lebowitz, and F. Shic, "Linking Volitional Preferences for Emotional Information to Social Difficulties A Game Approach using the Microsoft Kinect,” no. 3, pp. 588-594, 2015.

[12] J. Gabriel, C. Melo, and J. Machado, "Kinect system in home-based cardiovascular rehabilitation," no. 322, 2016.

[13] R. a Clark, S. Vernon, B. F. Mentiplay, K. J. Miller, J. L. Mcginley, Y. H. Pua, K. Paterson, and K. J. Bower, "Instrumenting gait assessment using the Kinect in people living with stroke: reliability 
and association with balance tests," J. Neuroeng. Rehabil., vol. 12, p. $15,2012$.

[14] a Mobini, S. Behzadipour, and M. Saadat, "Test-retest reliability of Kinect's measurements for the evaluation of upper body recovery of stroke patients.," Biomed. Eng. Online, pp. 1-13, 2015.

[15] W. Sommool, B. Battulga, T. K. Shih, and W. Hwang, "Using Kinect for Holodeck Classroom :," pp. 40-49, 2013.

[16] M. Nakamura, Y. Kitajima, J. Ota, T. Ogata, Z. Huang, A. Nagata, K. Aida, N. Kuwahara, J. Maeda, and M. Kanai-Pak, "The relationship between nursing students' attitudes towards learning and effects of self-learning system using Kinect," Lect. Notes Comput. Sci. (including Subser. Lect. Notes Artif. Intell. Lect. Notes Bioinformatics), vol. 8026 LNCS, no. PART 2, pp. 111-116, 2013.

[17] A. Rahman, "Multisensor Serious Game-Based Therapy Environment for Hemiplegic Patients," Int. J. Distrib. Sens. Networks, vol. 2015, 2015.

[18] H. Kayama, S. Nishiguchi, and M. Yamada, "Effect of a Kinectbased exercise game on improving executive cognitive performance in community - dwelling elderly," pp. 362-365, 2013.

[19] M. A.-R. D. González-Ortega, F.J. Díaz-Pernas, M. MartínezZarzuela, "A Kinect-based system for cognitive rehabilitation exercises monitoring," Comput. Methods Programs Biomed., vol. 113, no. 2, pp. 620-631, 2013.

[20] D. Webster and O. Celik, "Systematic review of Kinect applications in elderly care and stroke rehabilitation," J. Neuroeng. Rehabil., vol. 11, no. 1, pp. 1-24, 2014.

[21] S. Zelai, "KiMentia : Kinect based tool to help Cognitive Stimulation for individuals with Dementia," pp. 325-328, 2012. 